\title{
Booklet Sebagai Media Peningkatan Pengetahuan Tentang Pendidikan Seks Anak Usia Dini Pada Orang Tua
}

\author{
Anaa Murti Citra Putri Azzahra \\ Fakultas Psikologi, Universitas Muhammadiyah Jember \\ zzhic95@gmail.com \\ Iin Ervina \\ Fakultas Psikologi, Universitas Muhammadiyah Jember \\ iinervina@unmuhjember.ac.id \\ Erna Ipak Rahmawati \\ Fakultas Psikologi, Universitas Muhammadiyah Jember \\ ipakrahmawati@unmuhjember.ac.id
}

\begin{abstract}
Sexual violence in children has the impact of physical, mental, social and behavioral trauma in the short and long term. Therefore, prevention needs to be done, one of them is by providing sex education early on through parents. So parents need to be equipped with the knowledge of early childhood sex education. The purpose of this study was to determine the effectiveness of the booklet media for early childhood sex education on the knowledge and skills of parents in providing sex education for early childhood.

The method used is a quasi-experimental research model with a research design using pretest-posttest control group design. The sample used was 40 people with the criteria of parents with children aged 1-6 years. The study was conducted at Al-Fattah Kindergarten.

The results of this study indicate that the booklet is able to increase the knowledge of early childhood sex education in parents with a significance value (2-tailed) $0.038<0.05$ based on the pretest and posttest paired sample test. The average pretest score was 18.60 and increased by 1.00 after being given an early childhood sex education booklet with an average score of 19.60. The highest increase occurred in the aspects of children's birth, booklet can cognitively facilitate parents in understanding sex education material, affectively able to help the readiness and willingness of parents to act, and psychomotorally can help parents educate their children.
\end{abstract}

Keyword: booklet; sarly childhood sex education

\begin{abstract}
Abstrak
Kekerasan seksual pada anak memiliki dampak trauma fisik, mental, sosial maupun perilaku dalam jangka pendek maupun jangka panjang. Oleh karena itu perlu dilakukan pencegahan salah satunya dengan memberikan pendidikan seks
\end{abstract}


sejak dini melalui orang tua. Maka orang tua perlu dibekali oleh pengetahuan pendidikan seks anak usia dini.

Tujuan dari penelitian ini adalah untuk mengetahui efektifitas dari media booklet pendidikan seks anak usia dini terhadap pengetahuan dan keterampilan orang tua dalam memberikan pendidikan seks pada anak usia dini.

Metode yang digunakan adalah model penelitian kuasi eksperimen dengan desain penelitian menggunakan pretest-posttest control group design. Sampel yang digunakan berjumlah 40 orang dengan kriteria orang tua dengan anak usia 1-6 tahun. Penelitian dilakukan di TK Al-Fattah.

Hasil penelitian ini menunjukkan bahwa booklet mampu meningkatkan pengetahuan pendidikan seks anak usia dini pada orang tua dengan nilai signifikasi (2-tailed) $0,038<0,05$ berdasarkan uji sampel berpasangan pretest dan posttest, didapatkan skor rerata pretest sebesar 18,60 dan meningkat sebanyak 1,00 setelah diberi booklet pendidikan seks anak usia dini dengan nilai rerata 19,60. Peningkatan tertinggi terjadi pada aspek materi asal-usul anak, media booklet secara kognitif mampu memfasilitasi orang tua dalam memahami materi pendidikan seks, secara afektif mampu membantu kesiapan dan kesediaan orang tua untuk bertindak, dan secara psikomotor dapat membuat orangtua menyampaikan materi kepada anak.

Kata Kunci : media booklet; pendidikan seks anak usia dini

\section{Pendahuluan}

Kekerasan terhadap anak-anak meliputi kekerasan fisik, seksual, emosi, dan penolakan terhadap kehadiran anak. Kekerasan seksual pada anak yang selanjutnya akan disebut dengan istilah KSA, menurut Ervina (2015) adalah suatu bentuk penyiksaan anak di mana orang dewasa atau remaja yang lebih tua menggunakan anak untuk rangsangan seksual. Dampak KSA diantaranya adalah kecemasan, perilaku agresif, paranoid, gangguan stres paskah trauma, depresi, gangguan disasosiatif, penyalahgunaan obat-obatan terlarang, tertular penyakit kelamin, perilaku seksual menyimpang, ketakutan pada figur tertentu, dan masih banyak lainnya (Paramastri, 2011).

Noviana (2015) menjelaskan bahwa anak menjadi kelompok yang sangat rentan terhadap ancaman kekerasan seksual karena anak merupakan figur yang selalu membutuhkan perlindungan dari orang dewasa atau dengan kata lain anak berada pada posisi yang lemah. Hal inilah yang membuat anak menjadi tidak berdaya ketika diancam untuk tidak memberitahukan tindakan kekerasan seksual yang dialaminya. Hampir dari semua pelaku kekerasan seksual pada anak Jurnal Insight Fakultas Psikologi Universitas Muhammadiyah Jember | 403 
dilakukan oleh orang-orang terdekat dan biasanya merupakan figur yang disenangi oleh anak-anak seperti keluarga, kerabat, tetangga, teman ayah/ibu atau teman sebaya. Tidak ada satupun karakteristik khusus atau tipe kepribadian yang dapat diidentifikasi dari seorang pelaku kekerasan seksual terhadap anak. Dengan kata lain, siapapun dapat menjadi pelaku kekerasan seksual dan mengancam keselamatan anak.

Jumlah kasus kekerasan seksual yang terjadi di Kabupaten Jember yang ditangani oleh Polres Jember dalam rentang tahun 2014 hingga 2016 adalah sebanyak 251 kasus. Jumlah kasus terlapor tersebut relatif kecil setiap tahunnya, pada tahun 2014 tercatat 104 kasus, 2015 sebanyak 73 kasus dan 2016 tercatat sebanyak 74 kasus. Berdasarkan catatan kasus yang terlapor, angka-angka tersebut menunjukkan penurunan, namun demikian, data tersebut masih dapat bertambah karena tidak semua korban berani melapor ke kantor polisi dengan berbagai pertimbangan. Penurunan kasus tersebut juga tidak menjamin bahwa anak-anak usia dini di Kabupaten Jember aman dari tindak kekerasan seksual. Sebagian kasus tersebut tidak dapat diproses lebih lanjut secara hukum karena bukti kurang memadai atau pengaduan dicabut kembali oleh pelapor.

Banyaknya kasus kekerasan seksual menjadi alasan pentingnya dilakukan usaha pencegahan kekerasan seksual pada anak usia dini. Usaha pencegahan kekerasan seksual pada anak usia dini dapat dilakukan, salah satunya dengan memberikan pendidikan seks pada anak. Pada dasarnya pendidikan seks tidak serta merta diberikan secara gamblang mengenai sistem reproduksi, melainkan diberikan sesuai dengan rentang usia perkembangan anak. Pendidikan seks anak usia dini dapat diberikan oleh orang tua dan guru di sekolah. Pengetahuan orang tua mengenai pendidikan seks anak usia dini akan membantu anak menghindari ancaman kekerasan seksual. Pendidikan seks anak usia dini bukan mengajarkan anak untuk melakukan seks bebas ketika mereka dewasa kelak, melainkan memberikan pemahaman kepada anak mengenai kondisi tubuhnya, kondisi tubuh lawan jenisnya, serta menjaga dan menghindarkan anak dari kekerasan seksual. Meskipun begitu cara penyampaian pendidikan seks pada anak tidak boleh terlalu vulgar karena akan berdampak negatif (Jatmikowati, et all, 2015). 
Berdasarkan hasil wawancara dengan kepala sekolah dan beberapa wali murid ditemukan bahwa sekolah belum pernah memberikan kegiatan parenting dengan tema pendidikan seks untuk anak usia dini. Orang tua juga mengaku belum mendapatkan materi pendidikan seks anak usia dini. Orang tua menganggap bahwa pendidikan seks akan diketahui oleh anak dengan sendirinya. Bahwa KSA hanya mengancam anak perempuan saja dan menganggap bahwa anak laki-laki tidak lebih beresiko terhadap KSA, sementara berdasarkan data PPT Kab. Jember tahun 2014 (dalam Ervina, 2015) 10\% dari korban KSA adalah laki-laki.

Berdasarkan hasil wawancara sumber informasi orang tua mengenai pendidikan seks anak usia dini adalah pertukaran informasi yang disampaikan secara lisan dari lingkungan dan keluarga. Terlepas dari teori pendidikan seks anak usia dini yang sebenarnya, informasi pendidikan seks yang diterima oleh orang tua syarat budaya setempat seperti anak perempuan tidak boleh bermain larut malam, anak laki-laki dan perempuan harus dipisah ketika beranjak remaja, serta bagaimana perempuan melakukan perannya sesuai dengan budaya setempat. Hal ini sejalan dengan pendapat Kartono (dalam Septianingsih, 2016) terdapat beberapa penyebab orang tua sering tidak memberikan pendidikan seks kepada anak, diantara lain adalah orang tua menganggap seks adalah sesuatu hal yang tabu. Orang tua tidak mengetahui pentingnya pendidikan seks bagi anak. Orang tua tidak memiliki pengetahuan mengenai seks dan tidak mengetahui cara memberikan pedidikan seks. Orang tua merasa malu membicarakan masalah seks. Orang tua menganggap bahwa masalah seks pada akhirnya akan diketahui sendiri oleh anak. Orang tua merasa khawatir jika anak akan melakukan perbuatan menyimpang setelah diberikan penjelasan tentang seks.

Berdasarkan fenomena yang telah dipaparkan pengetahuan orangtua tentang pendidikan seks anak usia dini yang minim serta kesulitan orangtua dalam menyampaikan pendidikan seks kepada anak ini merupakan gambaran kebutuhan akan media pendidikan seks anak usia dini yang efektif agar orangtua dapat ikut berperan dalam pencegahan kekerasan seks pada anak. Penelitian yang dilakukan oleh Paramastri pada tahun 2006 tentang penilaian kebutuhan pencegahan dini 
kekerasan seksual anak menunjukkan bahwa siswa dan siswi sekolah dasar, guru, dan para ahli mengusulkan metode pendidikan kesehatan berupa ceramah, sarasehan, dan diskusi sedangkan media yang diusulkan adalah komik bergambar dan booklet. Selanjutnya, penelitian oleh Paramastri pada tahun 2007 tentang komik bergambar sebagai media pencegahan dini terhadap kekerasan seksual. Hasilnya menunjukkan bahwa komik bergambar dapat meningkatkan pengetahuan para siswa dan sisiwi kelas 5 SD.

Oleh karena itu dibuatnya media booklet pendidikan seks anak usia dini adalah bertujuan untuk meningkatkan pengetahuan orang tua mengenai ancaman kekerasan seksual, pendidikan seks anak usia dini dan meningkatkan keterampilan orang tua mengenai cara memberikan pendidikan seks kepada anak usia dini sesuai rentang usianya, sehingga anak mendapatkan pedidikan seks yang benar dan mampu menghindar dari ancaman kekerasan seksual.

\section{Metode}

Dalam penelitian ini menggunakan jenis penelitian true experimental design, dalam desain ini peneliti dapat mengontrol semua variabel luar yang mempengaruhi jalannya eksperimen. Desain penelitian ini menggunakan pretestposttest control group design, yaitu terdapat dua kelompok subyek yang kemudian diberi pretest untuk mengetahui keadaan adakah perbedaan antara kelompok eksperimen dan kelompok kontrol. Kelompok eksperimen diberikan perlakuan menggunakan media booklet dan kelompok kontrol tidak diberi perlakuan. Lokasi penelitian adalah di TK Al-Fattah Suco, Mumbulsari, Jember. Penelitian dilaksanakan pada 14 Mei 2018 hingga 22 Mei 2018.

\section{Hasil Penelitian dan Pembahasan}

Berdasarkan dari hasil uji analisa yang dilakukan dengan menggunakan teknik paired sample t-test SPSS 17 for windows terbukti bahwa terdapat perbedaan antara nilai pretest dan posttest menggunakan taraf signifikansi $5 \%$ yaitu dengan nilai signifikansi $0,038<0,05$ dan didapatkan juga nilai rata-rata pretest sebesar 18,60 dan nilai posttest sebesar 19,60. dari nilai tersebut 
menunjukkan adanya peningkatan antara skor pretest dan posttest sebesar 1 . Hal ini menunjukkan terdapat perbedaan pengetahuan orang tua sebelum dan sesudah diberi perlakuan. Jadi dapat dikatakan booklet pendidikan seks anak usia dini mampu meningkatkan pengetahuan pendidikan seks anak usia dini pada orang tua.

Peningkatan dapat terjadi karena pada kelompok perlakuan memiliki pendidikan dan umur yang sama rata. Dibuktikan dengan hasil penelitian bahwa $80 \%$ orang tua berusia 21-30 tahun. Usia 21-30 tahun tergolong usia dewasa awal dan dewasa akhir atau menuju lansia (Depkes, 2009). Hal ini sejalan dengan pernyataan Gummi (Pratiwi, 2017) bahwa usia 0-30 tahun merupakan tahapan pertumbuhan dan perkembangan yang berkelanjutan. Kematangan penuh dari fisik dan intelektual terdapat pada usia 0-30 tahun. Maka dapat disimpulkan bahwa pada rentang usia 21-30 tahun merupakan masa yang mudah untuk menerima informasi.

Selain umur pendidikan juga berpengaruh dalam menentukan hasil penelitian. Kedua kelompok dalam penelitian ini memiliki frekuensi tingkat pendidikan yang sama, yaitu pendidikan SD. Pada kelompok kontrol terdapat $80 \%$ orang tua yang berpendidikan SD dan $75 \%$ orang tua berpendidikan SD pada kelompok perlakuan. Nursalam (Pratiwi, 2017) bahwa proses belajar yang dialami seseorang dapat mengubah aspek pengetahuan (kognitif), sikap (afektif), dan keterampilan (psikomotor) dalam hal perilaku. Sesuai dengan pernyataan Permatasari (2008) bahwa seseorang akan mengintepretasi informasi yang didapat dengan baik apabila memiliki tingkat pendidikan yang tinggi, sehingga semakin tinggi tingkat pendidikan semakin mudah menerima informasi. Karena tingkat pendidikan formal orang tua sebagian besar berpendidikan SD hal ini menjelaskan mengapa meskipun terjadi peningkatan pengetahuan berdasarkan skor pretest dan posttest, selisih skor peningkatan pengetahuan tidak banyak. Selain pendidikan formal, pendidikan nonformal juga mempengaruhi hasil pretest-posttest orang tua. Berdasarkan wawancara lanjutan orang tua mengaku pendidikan seks pernah beberapakali mereka dapatkan dari kegiatan pengajian dan PKK, hal ini 
menjelaskan mengapa kategori tingkat pengetahuan pendidikan seks anak usia dini orang tua masuk dalam ketagori tinggi.

Booklet pendidikan seks anak usia dini dapat diterapkan dalam meningkatkan pengetahuan tentang pendidikan seks anak usia dini. Hal ini karena materi yang disajikan dalam booklet dikemas dalam bentuk lebih sederhana berbentuk gambar ilustrasi dan penjelasan ringkas yang mewakili materi pendidikan seks anak usia dini. Sehingga memudahkan orang tua untuk memahami dan mengaplikasikan kepada anak.

Peran booklet dalam penelitian ini adalah sebagai media peningkatan pengetahuan pendidikan seks anak usia dini pada orang tua. Penggunaan booklet sebagai alat perlakuan diharapkan mampu membantu visualisasi materi kepada orang tua dan mampu membuat orang tua mempelajari materi secara individual sehingga membantu orang tua berkonsentrasi terhadap materi dibandingkan dengan menggunakan media lain seperti power point atau ceramah. Selain itu pemberian booklet secara individual kepada orang tua diharapkan mampu membangkitkan ketertarikan terhadap materi yang disajikan. Dibuktikan dengan hasil peningkatan indikator afektif pada dua aspek materi pendidikan seksual yaitu pada aspek menghindarkan anak dari ancaman kekerasan seksual sebanyak satu poin dan pada aspek informasi mengenai asal usul anak sebanyak 12 poin. Sesuai dengan pernyataan Muslic (2010) bahwa aspek grafika media booklet dapat membuat pembaca akan menyenangi materi booklet yang dikemas dengan baik.

Hasil penelitian ini sejalan dengan penelitian yang dilakukan oleh Pratiwi (2017) bahwa terdapat peningkatan pengetahuan ibu setelah diberikan pengetahuan gizi seimbang pada balita dengan menggunakan media booklet. Booklet juga dapat memberikan kesan kepada pembaca jika disajikan dengan gambar yang menarik sehingga booklet tidak formal dan kaku (Nurfathiyah, 2014). Penelitian yang dilakukan oleh Puspitanigrum (2017) mengungkapkan bahwa dengan menggunakan media cetak remaja putri cenderung lebih mudah untuk memahami tentang muatan informasi karena informasi yang tercantum di dalam booklet ringan dan dapat dipelajari sendiri oleh remaja putri. 


\section{Kesimpulan}

Dari hasil penelitian yang telah dilakukan oleh peneliti media booklet dapat meningkatkan pengetahuan orang tua tentang pendidikan seks anak usia dini. Metode ini dapat menjadi alterfnatif untuk meningkatkan pengetahuan pendidikan seks anak usia dini pada orang tua. Hal ini dimaksudkan agar orang tua dapat memberikan anak pengetahuan tentang pendidikan seks sehingga anak dapat mengenali diri sendiri, menjaga tubuh dan terhindar dari ancaman kekerasan seksual.

\section{DAFTAR PUSTAKA}

Ervina, I., Widyarini, N. 2015. Kekerasan Seksual Pada Anak. Universitas Muhammadiyah Jember.

Jatmikowati, T.E. 2015. Model dan Materi Pendidikan Seks Anak Usia Dini Perspektif Gender Untuk Menghindarkan Sexual Abuse. Cakrawala Pendidikan, 434 - 448.

Noviana, I. 2015. Kekerasan Seksual Terhadap Anak : Dampak dan Pencegahannya. Sosio Informa Vol. 01, No. 1, 13 - 28.

Nurfathiyah, P. 2014. Pengaruh Penggunaan Ilustrasi dan Bahasa pada Media Buklet terhadap Peningkatan Pengetahuan Petani di Kabupaten Muara Jambi. Jurnal Penelitian Universitas Jambi Seri Sains. Jambi.

Nurhayati. 2009. Peningkatan Kemampuan Asertif Remaja Putri dalam Menolak Usikan Seksual Melalui Pelatihan Asertif. Jember: Fakultas Psikologi, Universitas Muhammadiyah Jember.

Muslich, M. 2007. KTSP Dasar Pemahaman dan Pengembangan. Jakarta: PT. Bumi Aksara.

Paramastri, I. 2011. Buklet sebagai Media Pencegahan terhadap Kekerasan Seksual pada Anak-anak. Jurnal Kesehatan Masyarakat Nasional. vol. 6, no. $2,77-84$.

Pratiwi, Y.F., Puspitasari, D. I. 2017. Effektifitas Penggunaan Media Booklet Terhadap Pengetahuan Gizi Seimbang Pada Ibu Balita Gizi Kurang Di Kelurahan Semanggi Kecamatan Pasar Kliwon Kota Surakarta. Jurnal Kesehatan, Vol. 10, No. 1. 
Puspitaningrum, W. 2017. Pengaruh Media Booklet Terhadap Pengetahuan Dan Sikap Remaja Putri Terkait Kebersihan Dalam Menstruasi Di Pondok Pesantren AL-Ishlah Demak Triwulan II Tahun 2017. Jurnal Kesehatan Masyarakat, Vol. 5 No. 4. 